\title{
Estimating optimum plot size with radiometer for experiments on soybeans treated with fungicide
}

\author{
Roger Nabeyama Michels ${ }^{1} \oplus$, Marcelo Giovanetti Canteri² ${ }^{2}$, Inês Cristina de Batista Fonseca² ${ }^{\circledR}$, \\ Marcelo Augusto Aguiar e Silva² ${ }^{2}$, Janksyn Bertozzi ${ }^{3} @$, Tatiane Cristina Dal Bosco ${ }^{4}$
}

\begin{abstract}
1 “Universidade Tecnológica Federal do Paraná”, Mechanical Engineering Department, Av. dos Pioneiros, 3131 - Jardim Morumbi, Londrina - PR, 86036-370, Londrina, Paraná, Brazil. ${ }^{2}$ "Universidade Estadual de Londrina”, Center for Agrarian Sciences, Rodovia Celso Garcia Cid, PR-445, Km 380 - Campus Universitário, PR, 86057-970, Londrina, Paraná, Brazil. “'Universidade Tecnológica Federal do Paraná”, Chemistry Department, Av. dos Pioneiros, 3131 - Jardim Morumbi, Londrina - PR, 86036-370, Londrina, Paraná, Brazil; “ “Universidade Tecnológica Federal do Paraná”, Department of Environmental Engineering, Av. dos Pioneiros, 3131 - Jardim Morumbi, Londrina - PR, 86036-370, Londrina, Paraná, Brasil

Corresponding Author: Roger Nabeyama Michels (rogernmichels@utfpr.edu.br)
\end{abstract}

Data de chegada: 21/05/2020. Aceito para publicação em: 20/08/2020.

$10.1590 / 0100-5405 / 238411$

\section{ABSTRACT}

Michels, R.N.; Canteri, M.G.; Fonseca, I.C.B.; Aguiar e Silva, M.A.; Bertozzi, J.; Tatiane Dal Bosco, C. Estimating optimum plot size with radiometer for experiments on soybeans treated with fungicide. Summa Phytopathologica, v.46, n.4, p.308-312, 2020.

Spectral remote sensing and proximal sensors are important tools for managing the plant-pathogen relationship. The lack of experimental planning and the probability of error in agricultural studies may result in work repetition and, consequently, in financial expenses and costs with human resources. To reduce such problems, determining the optimum size of the experimental plot for treatments is one of the adopted methods. The objective of this study was to estimate the optimum plot size for reflectance in soybeans that were treated with different fungicide levels according to the methods of modified maximum curvature and maximum distance. Reflectance readings were carried out for

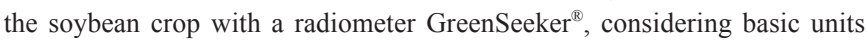
of $0.45 \mathrm{~m}^{2}$ in an area of ten rows, $10 \mathrm{~m}$ long, for each treatment. Treatments were applied to create a gradient of Asian soybean rust, varying the number of fungicide applications. Data were collected in two phenological stages (R5.5 and R6), obtaining 300 simulations of experimental area for each stage. Based on the results, the use of $5.40 \mathrm{~m}^{2}$ plots with a group of three rows, $4 \mathrm{~m}$ long, is recommended.

Keywords: NDVI. Maximum distance. Modified maximum curvature.

RESUMO

Michels, R.N.; Canteri, M.G.; Fonseca, I.C.B.; Aguiar e Silva, M.A.; Bertozzi, J.; Tatiane Dal Bosco, C. Estimativa do tamanho ótimo de parcela em experimentos com o radiômetro em soja tratada com fungicida. Summa Phytopathologica, v.46, n.4, p.308-312, 2020.

O sensoriamento remoto espectral e o sensor proximal são ferramentas importantes para gerenciar a relação planta-patógeno. A falta de planejamento experimental e a probabilidade de erro em estudos agrícolas podem resultar em retrabalho e, consequentemente, despesas financeiras e de recursos humanos. Uma maneira de reduzir esse problema é determinar o tamanho ótimo de parcela experimental para realização dos tratamentos. O objetivo deste estudo foi estimar o tamanho ótimo de parcela para refletância em soja que foi tratada com diferentes doses de fungicida, usando os métodos de curvatura máxima modificada e distância máxima.
As leituras de refletância foram realizadas na cultura de soja com o auxílio de um radiômetro GreenSeeker ${ }^{\circledR}$, com unidades básicas de $0,45 \mathrm{~m}^{2}$, em uma área de dez linhas, com 10 metros de comprimento, em cada tratamento. Os tratamentos foram aplicados para criar um gradiente da doença ferrugem asiática da soja, variando o número de aplicações de fungicidas. Os dados foram coletados em dois estágios fenológicos (R5.5 e R6), obtendo-se 300 simulações de áreas experimentais em cada estágio. Com base nos resultados, recomenda-se o uso de parcelas de $5,40 \mathrm{~m}^{2}$, com um grupo de três linhas, com $4 \mathrm{~m}$ de comprimento.

Palavras-chave: NDVI. Distância máxima. Curvatura máxima modificada.

Using technology to detect phenotypic reactions that occur during the plant-pathogen interaction has become more frequent in recent years (16). Spectral remote sensing and proximal sensing have been widely employed to manage lands and crops $(3,17)$, as well as to quantify damage caused by leaf diseases (4).

GreenSeeker $^{\circledR}$, produced by Trimble, is a portable device with an active spectral sensor that provides the normalized difference vegetation index (NDVI) via reflectance measurements, i.e., it has a light-emitting diode in the near-infrared (NIR: $770 \mathrm{~nm}$ ) and red (RED: $650 \mathrm{~nm}$ ) region and a receiver that absorbs the values reflected in the canopy, rapidly indicating nutritional and physiological conditions, stress, and potential yield by measuring the crop biomass $(1,19,20,21)$. This device accurately reflects the severity of foliar diseases and is a useful tool that precisely traces the level of leaf rust (15)

For a reliable conclusion of proximal sensing application, field experiments should show the least possible experimental errors and meet the statistical parameters (2). Adopting the correct experimental plot size is important to prevent work repetition, financial expenses and human resource losses, keeping experimental accuracy at an acceptable magnitude and maximizing the obtained information $(8,10)$.

In the study of plant diseases and fungicides, establishing the size and shape of an experimental plot can be empirical, based on the researchers' experience with a specific culture (13); however, there are methodologies to determine the optimum plot size (18). 
The modified maximum curvature method, proposed by Lessman \& Atkins (7), and the maximum distance method, proposed by Paranaíba (14), are methodologies for determining the optimum plot size, which need experiments with a culture of interest, i.e., without treatment distinction among the analyzed data, followed by the subdivision of the experimental area into small portions - basic experimental units (BEU) - from which data are collected independently, identifying the relative position. After data collection, contiguous plots are set to simulate plots of different sizes and shapes (6).

Thus, the objective of this manuscript was to estimate the optimum plot size for evaluating fungicide treatment on soybeans according to the modified maximum curvature and the maximum distance methods.

\section{MATERIALS AND METHODS}

The field experiment was conducted in Londrina, Paraná State, Brazil, located at latitude $23^{\circ} 19^{\prime} 40.92$ 'S and longitude $51^{\circ} 12^{\prime} 19.20^{\prime \prime} \mathrm{W}$, altitude of $560 \mathrm{~m}$, during the 2013/14 harvest, with the soybean cultivar 'Monsoy 6410 IPRO'.

Four areas of $12 \mathrm{~m}$ length and 12 rows width, $0.45 \mathrm{~m}$ between rows, were used; the useful area for data collection was ten rows $\times 10$ $\mathrm{m}$, i.e., $45 \mathrm{~m}^{2}$. Each plot was organized to simulate different intensities of Asian soybean rust, which was induced according to the number of scheduled fungicide applications (Table 1).

Table 1. Number and periods of sprays applied in the 2013/14 harvest to induce Asian soybean rust (P. pachyrhizi) gradient in the studied areas.

\begin{tabular}{cc}
\hline Number of sprays & Spraying (days after germination) \\
\hline 6 & $30,45,60,75,90,105$ \\
4 & $60,75,90,105$ \\
3 & $75,90,105$ \\
0 & - \\
\hline
\end{tabular}

The fungicide used to induce Asian soybean rust intensity gradient was the commercial mixture of Pyraclostrobin + Epoxiconazole $(66.5$ $+25 \mathrm{~g}_{\text {a.i. }} \mathrm{ha}^{-1}$ ) with spray volume of 200 L.ha $^{-1}$ plus mineral oil as a vehicle, at $500 \mathrm{~mL} \cdot \mathrm{ha}^{-1}$. The fungicide was applied with a $\mathrm{CO}^{2}$ pressurized backpack sprayer, containing four nozzles adjusted to fully cover the experimental unit, simulating a conventional (vehicular) sprayer.

Data on NDVI were collected in stages R5.5 and R6, between 8:00 a.m. and 8:30 a.m., from the ten central lines for each treatment, at 1-meter intervals, totaling $10 \mathrm{~m}$ per row and 100 readings per treatment, per stage. NDVI was measured with GreenSeeker ${ }^{\circledR}$, model RT100, from Trimble; data were collected at a distance of $0.8 \mathrm{~m}$ from the canopy.

To determine the optimum plot size, the modified maximum curvature method (MMC) - Lessman \& Atkins (7), was initially used. According to this methodology, the variability given by the coefficient of variation $\left(\mathrm{CV}_{\mathrm{x}}\right)$ and the size of the plot with $X$ basic experimental units is calculated by $C V_{x}=a X^{b}$, where $a$ and $b$ are the parameters to be estimated. The optimum plot size was estimated based on the equation:

$$
X_{0}=\exp \left\{\left[\frac{1}{2 b+2}\right] \log \left[\frac{(a b)^{2}(2 b+1)}{b+2}\right]\right\}
$$

In this case, $X_{0}$ is the abscissa value at the maximum curvature point, which corresponds to the optimum plot size (9).

More than one method is recommended to determine the optimum plot size (13). Thus, the method of maximum distance (MD) was also adopted in our study; its resolution is based on a curve $y c$ described by $C V_{x}=a X^{b}$ and a line $y r$ secant to that curve. The point of curve $y c$ was calculated (which was at the longest distance from line $y r$ ) as the line segment along that distance was perpendicular to line $y r(6)$.

The solution method presented by Lorentz (6) proposes that the line perpendicular to line $y r$ should be determined to find the requested point of curve $y c$. Such a line perpendicular to line $y r$ is called $y p$ and is calculated by $y_{p}=e x+f$. The angular coefficient $c$ and the linear coefficient $d$, both of line $y r$, are fixed and can be obtained from two points of line $y r$ which are common to the curve $y c$.

The points common to the curve and the line to the left are called $X_{C R i}$ and $Y_{C R i}$, while the common points to the right are called $X_{C R f}$ and $Y_{C R f}$ Thus, $c$ and $d$ are obtained, respectively, by:

$$
\begin{gathered}
c=\frac{y_{C R f}-y_{C R i}}{X_{C R f}-X_{C R i}} \\
\text { and } \\
d=y_{C R i}-c x_{C R i} \\
\text { or } \\
d=y_{C R f}-c x_{C R f}
\end{gathered}
$$

The expressions for $d$ are obtained by isolating it in the $y r$ equation, substituting the $\mathrm{X}_{\mathrm{CRi}}+\mathrm{Y}_{\mathrm{CRi}}$ point or the $\mathrm{X}_{\mathrm{CRf}}+\mathrm{Y}_{\mathrm{CRf}}$ point. The angular coefficient $e$ of line $y p$ is also fixed and can be obtained based on the condition that lines $y r$ and $y p$ are perpendicular to each other. Therefore:

$$
e=\frac{-1}{c}
$$

Determining the linear coefficient $f$ of line $y p$ is part of the iterative method proposed by Lorentz (6) and has the following solution:

$$
x_{R p j}=\frac{f-d}{c-e}
$$

The distance between points $X_{C j}+Y_{C j}$ and $X_{R p j}+Y_{R p j}$ of line $y p j$, which is perpendicular to $y r$, is given by:

$$
d_{c r}=\sqrt{\left(y_{C j}-y_{R p j}\right)^{2}+\left(x_{C j}-x_{R p j}\right)^{2}}
$$

The analyses were performed within each treatment and each soybean phenological stage (R5.5 and R6). Thus, according to Lorentz (6), each treatment was considered a blank experiment. Two phenological stages were chosen when significant differences in the NDVI values were found between treatments, i.e., areas with different Asian soybean rust intensities.

To determine the optimum plot size, basic experimental units (BEU) of NDVI data should be grouped. Every possible simulation is shown in Table 2, considering width as meters and length $=0.45 \mathrm{~m}$ (distance between rows) for each simulation or unit, relation between length and width $(\mathrm{LxW})$, plot size as $\mathrm{m}^{2}$, type of grouping and number of plots. The BEU in this study are considered $0.45 \mathrm{~m}^{2}$, i.e., $1 \mathrm{~m}$ long and $0.45 \mathrm{~m}$ wide. 
Table 2. Number of simulations, width (W) and length (L) of simulations, $\mathrm{L} \times \mathrm{W}$ combination, plot size $\left(\mathrm{m}^{2}\right)$, type of grouping $(\mathrm{m})$ and total number of plots.

\begin{tabular}{|c|c|c|c|c|c|c|}
\hline Simulation & Width & Length & $\mathbf{L} \times \mathbf{W}$ & $\begin{array}{l}\text { Size } \\
\left(\mathrm{m}^{2}\right) \\
\end{array}$ & $\begin{array}{c}\text { Type of } \\
\text { Grouping }\end{array}$ & $\begin{array}{l}\text { Number } \\
\text { of plots }\end{array}$ \\
\hline 1 & 1 & 1 & 1 & 0.45 & $0.45 \times 1.00$ & 100 \\
\hline 2 & 2 & 1 & 2 & 0.90 & $0.90 \times 1.00$ & 50 \\
\hline 3 & 3 & 1 & 3 & 1.35 & $1.35 \times 1.00$ & 30 \\
\hline 4 & 4 & 1 & 4 & 1.80 & $1.80 \times 1.00$ & 20 \\
\hline 5 & 5 & 1 & 5 & 2.25 & $2.25 \times 1.00$ & 20 \\
\hline 6 & 6 & 1 & 6 & 2.70 & $2.70 \times 1.00$ & 10 \\
\hline 7 & 7 & 1 & 7 & 3.15 & $3.15 \times 1.00$ & 10 \\
\hline 8 & 8 & 1 & 8 & 3.60 & $3.60 \times 1.00$ & 10 \\
\hline 9 & 9 & 1 & 9 & 4.05 & $4.05 \times 1.00$ & 10 \\
\hline 10 & 10 & 1 & 10 & 4.50 & $4.50 \times 1.00$ & 10 \\
\hline 11 & 1 & 2 & 2 & 0.90 & $0.45 \times 2.00$ & 50 \\
\hline 12 & 1 & 3 & 3 & 1.35 & $0.45 \times 3.00$ & 30 \\
\hline 13 & 1 & 4 & 4 & 1.80 & $0.45 \times 4.00$ & 20 \\
\hline 14 & 1 & 5 & 5 & 2.25 & $0.45 \times 5.00$ & 20 \\
\hline 15 & 1 & 6 & 6 & 2.70 & $0.45 \times 6.00$ & 10 \\
\hline 16 & 1 & 7 & 7 & 3.15 & $0.45 \times 7.00$ & 10 \\
\hline 17 & 1 & 8 & 8 & 3.60 & $0.45 \times 8.00$ & 10 \\
\hline 18 & 1 & 9 & 9 & 4.05 & $0.45 \times 9.00$ & 10 \\
\hline 19 & 1 & 10 & 10 & 4.50 & $0.45 \times 10.00$ & 10 \\
\hline 20 & 2 & 2 & 4 & 1.80 & $0.90 \times 2.00$ & 25 \\
\hline 21 & 3 & 2 & 6 & 2.70 & $1.35 \times 2.00$ & 15 \\
\hline 22 & 4 & 2 & 8 & 3.60 & $1.80 \times 2.00$ & 10 \\
\hline 23 & 5 & 2 & 10 & 4.50 & $2.25 \times 2.00$ & 10 \\
\hline 24 & 6 & 2 & 12 & 5.40 & $2.70 \times 2.00$ & 5 \\
\hline 25 & 7 & 2 & 14 & 6.30 & $3.15 \times 2.00$ & 5 \\
\hline 26 & 8 & 2 & 16 & 7.20 & $3.69 \times 2.00$ & 5 \\
\hline 27 & 9 & 2 & 18 & 8.10 & $4.05 \times 2.00$ & 5 \\
\hline 28 & 10 & 2 & 20 & 9.00 & $4.50 \times 2.00$ & 5 \\
\hline 29 & 2 & 3 & 6 & 2.70 & $0.90 \times 3.00$ & 15 \\
\hline 30 & 3 & 3 & 9 & 4.05 & $1.35 \times 3.00$ & 9 \\
\hline 31 & 4 & 3 & 12 & 5.40 & $1.80 \times 3.00$ & 6 \\
\hline 32 & 5 & 3 & 15 & 6.75 & $2.25 \times 3.00$ & 6 \\
\hline 33 & 6 & 3 & 18 & 8.10 & $2.70 \times 3.00$ & 3 \\
\hline 34 & 7 & 3 & 21 & 9.45 & $3.15 \times 3.00$ & 3 \\
\hline 35 & 8 & 3 & 24 & 10.80 & $3.60 \times 3.00$ & 3 \\
\hline 36 & 9 & 3 & 27 & 12.15 & $4.05 \times 3.00$ & 3 \\
\hline 37 & 10 & 3 & 30 & 13.50 & $4.50 \times 3.00$ & 3 \\
\hline 38 & 2 & 4 & 8 & 3.60 & $0.90 \times 4.00$ & 10 \\
\hline 39 & 3 & 4 & 12 & 5.40 & $1.35 \times 4.00$ & 6 \\
\hline 40 & 4 & 4 & 16 & 7.20 & $1.80 \times 4.00$ & 4 \\
\hline 41 & 5 & 4 & 20 & 9.00 & $2.25 \times 4.00$ & 4 \\
\hline 42 & 6 & 4 & 24 & 10.80 & $2.70 \times 4.00$ & 2 \\
\hline 43 & 7 & 4 & 28 & 12.60 & $3.15 \times 4.00$ & 2 \\
\hline 44 & 8 & 4 & 32 & 14.40 & $3.60 \times 4.00$ & 2 \\
\hline 45 & 9 & 4 & 36 & 16.20 & $4.05 \times 4.00$ & 2 \\
\hline 46 & 10 & 4 & 40 & 18.00 & $4.50 \times 4.00$ & 2 \\
\hline 47 & 2 & 5 & 10 & 4.50 & $0.90 \times 5.00$ & 10 \\
\hline 48 & 3 & 5 & 15 & 6.75 & $1.35 \times 5.00$ & 6 \\
\hline 49 & 4 & 5 & 20 & 9.00 & $1.80 \times 5.00$ & 4 \\
\hline 50 & 5 & 5 & 25 & 11.25 & $2.25 \times 5.00$ & 4 \\
\hline 51 & 6 & 5 & 30 & 13.50 & $2.70 \times 5.00$ & 2 \\
\hline 52 & 7 & 5 & 35 & 15.75 & $3.15 \times 5.00$ & 2 \\
\hline
\end{tabular}

\begin{tabular}{ccccccc}
\hline Simulation & Width & Length & $\mathbf{L} \times \mathbf{W}$ & $\begin{array}{c}\text { Size } \\
\left.\mathbf{( m}^{2}\right)\end{array}$ & $\begin{array}{c}\text { Type of } \\
\text { Grouping }\end{array}$ & $\begin{array}{c}\text { Number } \\
\text { of plots }\end{array}$ \\
\hline 53 & 8 & 5 & 40 & 18.00 & $3.60 \times 5.00$ & 2 \\
54 & 9 & 5 & 45 & 20.25 & $4.05 \times 5.00$ & 2 \\
55 & 10 & 5 & 50 & 22.50 & $4.50 \times 5.00$ & 2 \\
56 & 2 & 6 & 12 & 5.40 & $0.90 \times 6.00$ & 5 \\
57 & 3 & 6 & 18 & 8.10 & $1.35 \times 6.00$ & 3 \\
58 & 4 & 6 & 24 & 10.80 & $1.80 \times 6.00$ & 2 \\
59 & 5 & 6 & 30 & 13.50 & $2.25 \times 6.00$ & 2 \\
60 & 2 & 7 & 14 & 6.30 & $0.90 \times 7.00$ & 5 \\
61 & 3 & 7 & 21 & 9.45 & $1.35 \times 7.00$ & 3 \\
62 & 4 & 7 & 28 & 12.60 & $1.80 \times 7.00$ & 2 \\
63 & 5 & 7 & 35 & 15.75 & $2.25 \times 7.00$ & 2 \\
64 & 2 & 8 & 16 & 7.20 & $0.90 \times 8.00$ & 5 \\
65 & 3 & 8 & 24 & 10.80 & $1.35 \times 8.00$ & 3 \\
66 & 4 & 8 & 32 & 14.40 & $1.80 \times 8.00$ & 2 \\
67 & 5 & 8 & 40 & 18.00 & $2.25 \times 8.00$ & 2 \\
68 & 2 & 9 & 18 & 8.10 & $0.90 \times 9.00$ & 5 \\
69 & 3 & 9 & 27 & 12.15 & $1.35 \times 9.00$ & 3 \\
70 & 4 & 9 & 36 & 16.20 & $1.80 \times 9.00$ & 2 \\
71 & 5 & 9 & 45 & 20.25 & $2.25 \times 9.00$ & 2 \\
72 & 2 & 10 & 20 & 9.00 & $0.90 \times 10.00$ & 5 \\
73 & 3 & 10 & 30 & 13.50 & $1.35 \times 10.00$ & 3 \\
74 & 4 & 10 & 40 & 18.00 & $1.80 \times 10.00$ & 2 \\
75 & 5 & 10 & 50 & 22.50 & $2.25 \times 10.00$ & 2 \\
\hline & & & & & &
\end{tabular}

To obtain an $\mathrm{R}^{2}$ (coefficient of determination) of greater significance, all calculations for determining the optimum plot size were made, and the simulations from 1 to 75,1 to 50 and 1 to 25 (Table 2) were used.

\section{RESULTS AND DISCUSSION}

Asian soybean rust is an end-of-cycle disease; therefore, NDVI data were obtained in stages R5.5 and R6, when the disease gradient was greater, as shown in Table 3 .

Table 3. Difference in the disease gradient demonstrated by the NDVI values among the treatments with $6,4,3$ and 0 fungicide sprays in stages R5.5 and R6. The letters show statistical differences according to Scott Knott test at 5\% significance.

\begin{tabular}{ccc}
\hline Number of Sprays & $\mathbf{R 5 . 5}$ & $\mathbf{R 6}$ \\
\hline 6 & $0.678 \mathrm{c}$ & $0.319 \mathrm{a}$ \\
4 & $0.639 \mathrm{c}$ & $0.346 \mathrm{~b}$ \\
3 & $0.480 \mathrm{~b}$ & $0.354 \mathrm{~b}$ \\
0 & $0.370 \mathrm{a}$ & $0.288 \mathrm{a}$ \\
\hline
\end{tabular}

To calculate the optimum plot size according to the MMC method, the values $a$ and $b$ presented by Lessman \& Atkins (7) should be estimated, while based on the MD method, the values $c, d$, and $e$ of the linear and angular coefficients of lines $y r$ and $y p$ should also be obtained (6). They are represented in Table 4 considering the coefficient of variation obtained according to Table 2 .

For the two stages of NDVI data collection (R5.5 and R6), from 75, 
Table 4 - Values from the calculation of $a$ and $b$, angular coefficient $c$ and linear coefficient $d$ of line $y r$, angular coefficient $e$ of line $y p$ and $\mathrm{R}^{2}$ using the Coefficient of Variation (CV) for treatments with different fungicide sprays in stages R5.5 and R6, within simulations with 75, 50 and 25 possibilities.

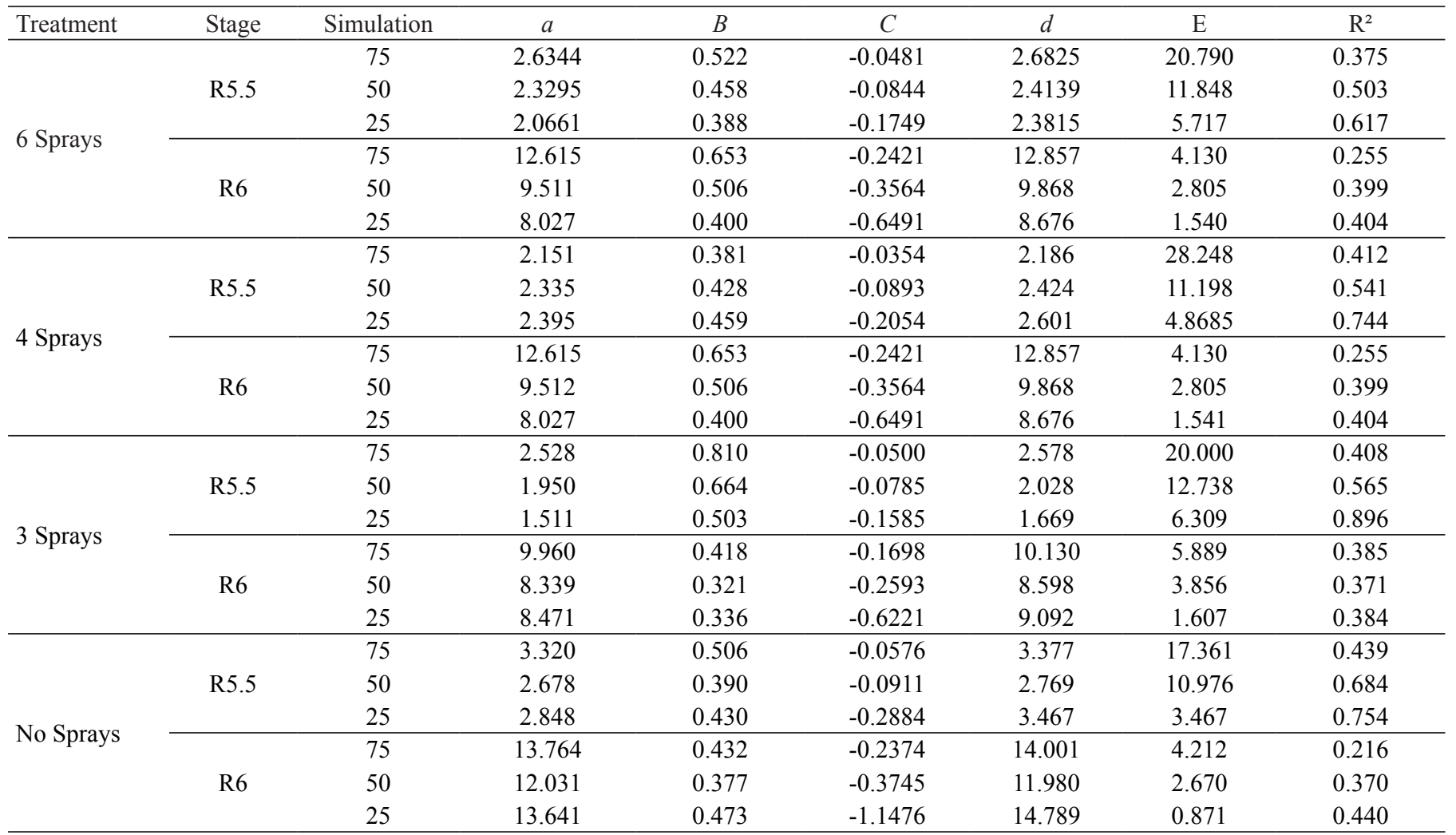

Table 5 - Combination of length and width $(\mathrm{L} \times \mathrm{W})$ and optimum plot size $\left(\mathrm{m}^{2}\right)$ obtained according to the methods Modified Maximum Curvature (MMC) and Maximum Distance (MD) for Coefficient of Variation (CV) data and simulations with 75, 50 and 25 possibilities in stages R5.5 and R6.

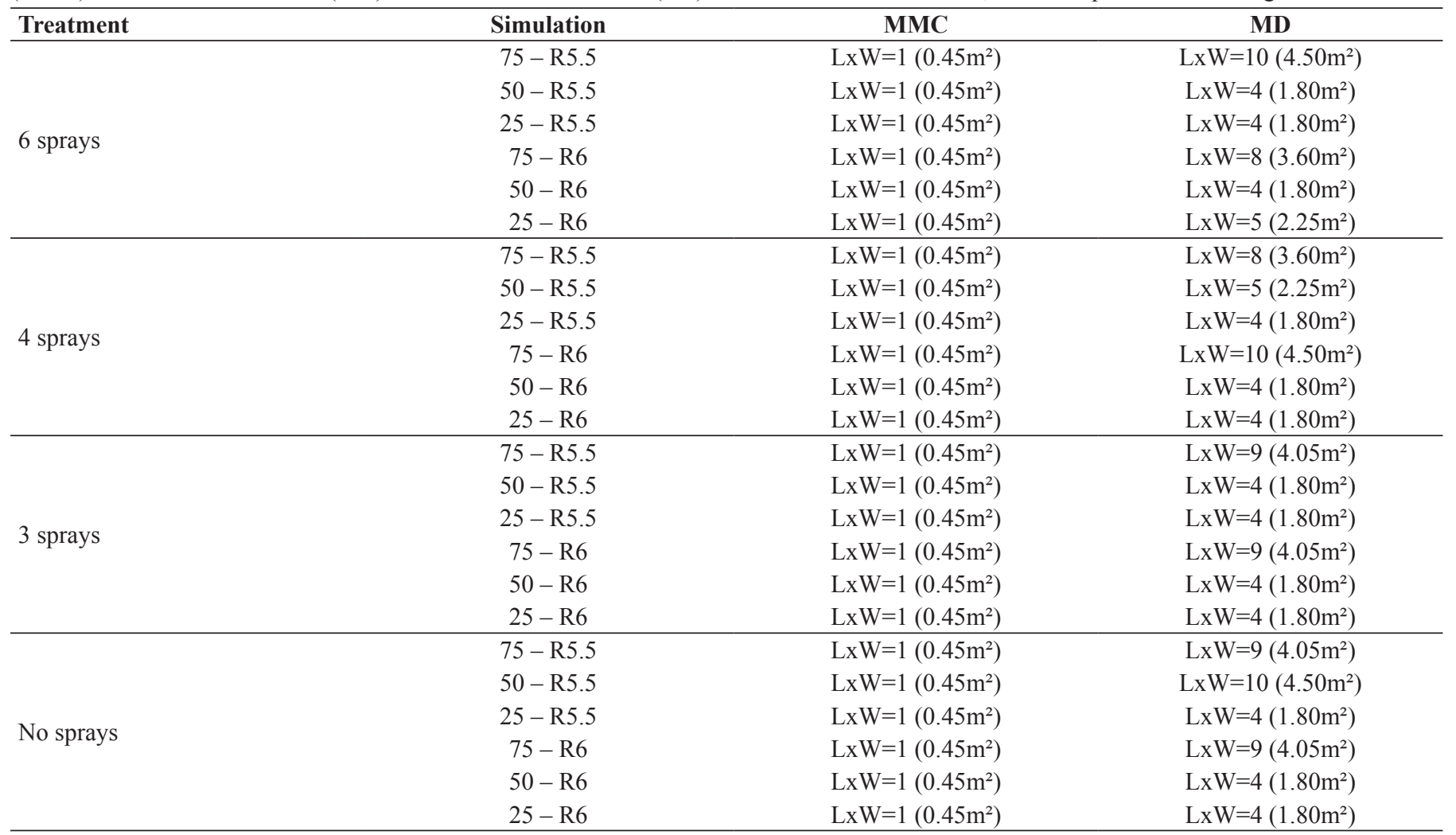


50 , and 25 simulation areas according to the MMC method, considering all four treatments and using the coefficient of variation, the optimum plot size was the area of $0.45 \mathrm{~m}^{2}$, with length $\mathrm{x}$ width relation equal to 1, i.e., an area that is the BEU (Table 5).

Based on the MD method, for treatments with 6, 4 and without fungicide sprays, the optimum plot size was $4.50 \mathrm{~m}^{2}(\mathrm{~L} \times \mathrm{W}=10)$, while for the treatment with 3 sprays, it was $4.05 \mathrm{~m}^{2}(\mathrm{~L} \times \mathrm{W}=9)$.

According to Paranaíba (13), the modified maximum curvature method can underestimate the plot size due to the low values of the coefficient of variation, which, according to Lorentz (5), influences the optimum plot size calculation.

Moraes (12) stated that, to obtain higher quality data, the largest plot size must be adopted. Thus, the optimum plot size for reflectance studies in soybeans is $4.50 \mathrm{~m}^{2}$, with two 5-m rows; adopting immediately higher $\mathrm{L} \times \mathrm{W}$ is also recommended, and in this case, $\mathrm{L} \times \mathrm{W}=12$ or 5.40 $\mathrm{m}^{2}$, with a group of three 4-m rows. This plot size is the same as that adopted by Michels et al. (11) in their project to examine the effects of different fungicide applications in soybeans; however, their plot size was inferior to the one used by Koga (5), who established a $10 \mathrm{~m}^{2}$ area to evaluate the fungicide effect on Asian soybean rust development, as well as on control effectiveness and soybean productivity.

\section{CONCLUSION}

The maximum distance method allowed estimating the optimum plot size.

Thus, in studies focused on reflectance measurements for the Asian soybean rust pathosystem, the use of $5.40 \mathrm{~m}^{2}$ plots is recommended, with groups of three rows of $4 \mathrm{~m}$ each.

\section{REFERENCES}

1. Anderson, H.B.; Nilsen, L.; Tommervik, H.; Karlsen, S.R.; Nagai, S.; Cooper, E.J. Using ordinary digital cameras in place of near-infrared sensors to derive vegetation indices for phenology studies of High Arctic vegetation. Remote Sensing, Basel, v.8, p.1-17, 2016. DOI: https://doi. org $/ 10.3390 /$ rs 8100847

2. Cargnelutti Filho, A.; Lavezo, A.; Bem, C.M.; Carini, F.; Schabarum, D.E.; Bandeira, C.T.; Kleinpaul, J.A.; Wartha, C.A.; Silveira, D.L.; Pezzini, R.V.; Thomasi, R.M.; Simões, F.M.; Neu, I.M.M. Plot size related to numbers of treatments and replications, and experimental precision in dwarf pigeon pea. Bragantia, Campinas, v.77, p.212-220, 2018. DOI: http://dx.doi. org/10.1590/1678-4499.2017085

3. Kipp, S.; Mistele, B.; Schmidhalter, U. The performance of active spectral reflectance sensors as influenced by distance, device temperature and light intensity. Computer and Electronic in Agriculture, Amsterdam, v.100, p.24-33, 2014. DOI: https://doi.org/10.1016/j.compag.2013.10.007

4. Hikishima, M.; Canteri, M.G.; Godoy, C.V.; Koga, L.J.; Silva, A.J da. Quntificação de danos e relações entre severidade, medidas de refletância e produtividade no patosistema ferrugem asiática da soja. Tropical Plant Pathology, Brasília, v.35, n.2, p.96-103, 2010. DOI: https://doi.org/10.1590/ S1982-56762010000200004.

5. Koga, L.J.; Canteri, M.G.; Calvo, E. S.; Martins, D.C.; Xavier, S.A.; Harata, A.; Kiihl, R.A.S. Managing soybean rust with fungicides and varieties of the early/semi-early intermediate maturity groups. Tropical Plant Pathology, Brasília, v.39, p.129-133, 2014. DOI: http://dx.doi.org/10.1590/ S1982-56762014000200003.
6. Lorentz, L.H.; Erichsen, R.; Lúcio, A.D. Proposta de método para estimação de tamanho de parcela para culturas agrícolas. Revista Ceres, Viçosa, v.59, p.772-780, 2012. DOI: http://dx.doi.org/10.1590/S0034737X2012000600006

7. Lessman, K.J.; Atkins, R.E. Comparisons of planning arrangements and estimates of optimum hill plot for grain sorghum yield tests. Crop Science, Madison, v.3, p.477-481, 1963. DOI: https://doi.org/10.2135/ cropsci1963.0011183X000300060010x

8. Lúcio, A.D.; Sari, B.G. Planning and implementing experiments and analyzing experimental data in vegetable crops: problems and solutions. Horticultura Brasileira, Brasília, v.35, p.316-327, 2017. DOI: http:// dx.doi.org/10.1590/s0102-053620170302

9. Meier, V.D.; Lessman, K.J. Estimation of optimum field plot shape and size for testing yield in Crambe abyssinica Hochst. Crop Science, Madison, v.11, p.648-650, 1971. DOI: https://doi.org/10.2135/cropsci1971.0011183X001100050013x

10. Michels, R.N.; Canteri, M.G.; Fonseca, I.C.B.; Aguiar E Silva, M.A., França, J.A. Estimation of optimal size of plots for experiments with radiometer in beans. African Journal of Biotechnolgy, Lagos, v.14, p.2361-2366, 2015. DOI: http://dx.doi.org/10.5897/AJB2014.13984

11. Michels, R.N.; Bonafé, E.G.; Figueiredo, L.; Suzuki, R.M.; Tonin, L.D.; Montanher, P.F.; Martins, A.F.; Visentainer, J.V.; Canteri, M.G.; Aguiar E Silva, M.A. de. Effects of different numbers of fungicide application on the proximate composition of soybean. Journal of the Brazilian Chemical Society, Campinas, v.27, p.1727-1735, 2016. DOI: http://dx.doi. org/10.5935/0103-5053.20160053

12. Morais, A.R. de, Araújo, A.G. de, Pasqual, M., Peixoto, A.P.B. Estimação do tamanho de parcela para experimento com cultura de tecidos em videira. Semina: Ciências Agrárias, Londrina, v. 35, n. 1, p. 113-124, 2014.

13. Oliveira, S.J.R.; Storck, L.; Lopes, S.J.; Lúcio, A.D.; Feijó, S.; Damo, H.P. Plot size and experimental unit relationship in exploratory experiments. Scientia Agricola, Piracicaba, v.62, p.585-589, 2005. DOI: http://dx.doi. org/10.1590/S0103-90162005000600012

14. Paranaíba, P.F.; Morais, A.R.; Ferreira, D.F. Tamanho ótimo de parcela experimentais: comparação de métodos em experimento de trigo e mandioca. Revista Brasileira de Biometria, Lavras, v.27, p.71-81, 2009.

15. Pretorius, Z.A.; Lan, C.X.; Prins, R.; Knight, V.; Mclaren, N.W.; Singh, R.P.; Bender, C.M.; Kloppers, F.J. Application of remote sensing to identify adult plant resistance loci to stripe rust in two bread wheat mapping populations. Precision Agriculture, Monticello, v.18, p.411-428, 2017. DOI: https://doi. org/10.1007/s11119-016-9461-x

16. Simko, I.; Jimenez-Berni, J.A.; Sirault, X.R.R. Phenomic approaches and tools for phytopathologists. Phytopathology, St. Paul, v.107, p.6-17, 2017. DOI: https://doi.org/10.1094/PHYTO-02-16-0082-RVW

17. Stocker, V.; Souza, E.G.; Johann, J.A.; Beneduzzi, H.; Silva, F.O. Effect of height, tilt and twist angles of an active reflectance sensor on NDVI measurements. Engenharia Agrícola, Jaboticabal, v.39, p.96-108, 2019. DOI: https://doi.org/10.1590/1809-4430-eng.agric.v39nep96-108/2019

18. Storck, L.; Lúcio, A.D.; Krause, W.; Araújo, A.V.; Silva, C.A. Scaling the number of plants per plot and number of plots per genotype of yellow passion fruit plans. Acta Scientiarum. Agronomy, Maringá, v.36, p.73-78, 2014. DOI: http://dx.doi.org/10.4025/actasciagron.v36i1.17697

19. Swamy, M.; Umesh, M.R.; Ananda, N.; Shanwad, U.K.; Amaregouda, A.; Manjunath, A. Precision nitrogen management for rabi sweet corn (Zea mays saccharata L.) through decision support tools. Journal of Farm Sciences, Sikandra, v.29, p.14-18, 2016.

20. Sylvester, P.N.; Kleczewski, N.M. Evaluation of foliar fungicide programs in mid-Atlantic winter wheat production systems. Crop Protection, Amsterdam, v.103, p.103-110, 2018. DOI: https://doi.org/10.1016/j.cropro.2017.09.012

21. Winterhalter, B.M.L.; Schmidhalter, U. Evaluation of active and passive sensor systems in the field to phenotypes maize hybrids with high-throughput. Field Crops Research, Amsterdam, v.154, p.236-245, 2013. DOI: https:// doi.org/10.1016/j.fcr.2013.09.006 